\title{
UJI TOKSISITAS AKUT LIMBAH CAIR RUMAH MAKAN TERHADAP IKAN MAS (Cyprinus Carpio L.) \\ Yonky Dwi Putra ${ }^{1)}$, Diah Wulandari ${ }^{2)}$, Laili Fitria ${ }^{1)}$
}

${ }^{1)}$ Program Studi Teknik Lingkungan Jurusan Teknik Sipil Fakultas Teknik Universitas Tanjungpura, Pontianak

2) Jurusan Biologi Fakultas MIPA Universitas Tanjungpura, Pontianak

Email : YonkyDPutra@yahoo.com

\begin{abstract}
ABSTRAK
Keadaan air sungai di Kota Pontianak saat ini semakin mengkhawatirkan, dimana semakin banyak industri dan tempat usaha yang bermunculan. Salah satunya usaha rumah makan yang membuang limbahnya ke badan air tanpa pengolahan. Hal ini menjadi salah satu sumber pencemar perairan yang menyebabkan kematian biota air. Penelitian ini bertujuan untuk mengetahui nilai $\mathrm{LC}_{50}$, mengetahui karakteristik limbah cair rumah makan di Kota Pontianak dan memberikan rekomendasi bagi pemerintah. Sampel limbah cair diambil dari sisa pencucian bahan makanan dari pagi hingga siang hari. Uji toksisitas akut dilakukan dengan metode statis dalam waktu 24 jam menggunakan hewan uji ikan mas (Cyprinus carpio L) setelah itu dibuat variasi konsentrasi untuk menentukan nilai konsentrasi yang menyebabkan kematian hewan 50\% dengan uji pendahuluan dan uji lanjut. Hasil uji Parameter BOD, TSS, minyak lemak, pH dan suhu limbah cair rumah makan masing-masing sebesar 692,48 mg/l; 1700 mg/l; 46 mg/l; 6,59 dan 25,8 OC. Nilai parameter limbah rumah makan tersebut melewati baku mutu KEP/MENLH/ No. 5 Tahun 2014 tentang Baku Mutu Limbah Cair Domestik. Nilai LC ${ }_{50}$ rata-rata didapatkan 0,614\% dan rekomendasi yang bisa diberikan kepada pemerintah yaitu penegasan tentang adanya IPAL di setiap rumah makan seperti yang tercantum di dalam PERDA/WALIKOTA/03/2004.
\end{abstract}

Kata kunci : toksisitas akut, limbah cair rumah makan, ikan mas (Cyprinus carpio L.)

\begin{abstract}
The condition of river water in Pontianak was getting extremely worrisome related to the emerging of many industries and restaurants. One of the causes was the waste from a restaurant which being dumped at the river without any process. It would be the source for water pollutants that cause the death of biotic water. this study was aimed to find out the value of $L C_{50}$, find out the characteristics of Liquid waste from the restaurant in Pontianak and give a reccomendation to government. The sample was taken from the residue of food ingredients which had been wasted from morning into afternoon. The test of critical toxicity was conducted by static method in 24 hours using the carp (Cyprinus carpio L.) as the subject, after that made some variant of concentration between wastewater and water to decided the value of concentration which causes $50 \%$ mortality of animals with finding range test and definitive test. The results of each parameter which consists of BOD, TSS, oil-grease, $p H$ and the temperature of waste water from the restaurant were 692,48 $\mathrm{mg} / \mathrm{l} ; 1700 \mathrm{mg} / \mathrm{l} ; 46 \mathrm{mg} / \mathrm{l} ; 6,59$ dan $25,8{ }^{\circ} \mathrm{C}$. . The value of the liquid waste from the restaurant was beyond the standard of KEP/MENLH/ No.5 Tahun 2014 which regulates the standard domestic waste water. The average value of $L C_{50}$ was $0,614 \%$ and the reccomendation who can give to government is affirmation of wastewater treatment at each restaurant as noted in PERDA/WALIKOTA/03/2004.
\end{abstract}

Keywords: Acute toxicity, Restaurant Wastewater, Carp (Cyprinus carpio L.). 


\section{PENDAHULUAN}

Keadaan air sungai di Kota Pontianak saat ini semakin mengkhawatirkan. Banyak industri dan tempat usaha yang membuang limbahnya ke badan air, salah satunya adalah rumah makan. Rumah makan adalah suatu usaha yang dapat dikategorikan berkembang pesat seiring dengan meningkatnya jumlah penduduk dan kebutuhan masyarakat untuk makan. Setiap rumah makan pasti menghasilkan limbah cair maupun padat. Kebiasaan pengelola rumah makan langsung membuang limbah cair tersebut ke badan air terdekat dapat membahayakan bagi lingkungan, manusia dan biota air.

Limbah cair rumah makan memiliki pengertian limbah yang berasal dari kegiatan operasional suatu rumah makan, yang dimulai dari pemilahan dan pencucian bahanbahan baku, pengolahan makanan dan pencucian peralatan makanan. Berdasarkan Keputusan Menteri Lingkungan Hidup No. 5 Tahun 2014 limbah rumah makan termasuk kedalam limbah domestik yang terdiri dari parameter BOD, TSS, pH, minyak dan lemak.

Efek dari limbah rumah makan dalam perairan tidak langsung terjadi seketika, tetapi berefek jangka panjang. Limbah rumah makan mengandung limbah organik yang dapat membusuk sehingga menimbulkan perubahan warna serta bau yang tidak enak. Limbah rumah makan juga bersifat toksik bagi kehidupan biota air sehingga menyebabkan kematian maupun penurunan populasi biota air di badan air. Tingkat toksisitas dari limbah rumah makan dapat ditentukan dari nilai $\mathrm{LC}_{50}$. Nilai $\mathrm{LC}_{50}$ di perairan memiliki kriteria untuk menentukan apakah limbah tersebut bersifat toksik kuat, sedang atau non toksik (Rossianna, 2006).

Ikan mas (Cyprinus carpio L) adalah salah satu organisme perairan yang sangat peka terhadap perubahan lingkungan (Husni, 2012). Uji toksisitas dengan menggunakan ikan mas juga dijadikan sebagai salah satu aspek monitoring pencemaran dini kualitas air (early warning system). Selain itu mengingat belum adanya data mengenai tingkat toksisitas dari limbah domestik atau limbah rumah makan terhadap ikan mas maka penelitian ini perlu dilakukan.

\section{METODOLOGI PENELITIAN}

\section{A. LOKASI DAN WAKTU PENELITIAN}

Penelitian dilaksanakan di Laboratorium Teknik Lingkungan Universitas Tanjungpura. Sedangkan untuk analisis sampel limbah rumah makan dilakukan di PT.SUCOFINDO Kota Pontianak. Waktu penelitian dimulai dari 5 Agustus 2015 sampai dengan 30 Agustus 2015.

\section{B. ALAT DAN BAHAN}

- Alat

Alat-alat yang digunakan dalam penelitian ini antara lain wadah pemeliharaan dan pengujian toksisitas dengan kapasitas volume $20 \mathrm{~L}$ air sebanyak 12 buah masing-masing wadah diisi 10 ekor ikan mas berumur 1-1,5 bulan, gayung plastik, aerator 12 buah, gelas ukur $500 \mathrm{ml}$, gelas ukur $10 \mathrm{ml}$, gelas ukur $250 \mathrm{ml}$, termometer dan $\mathrm{pH}$ meter.

- Bahan

Bahan-bahan yang digunakan dalam penelitian ini antara lain sampel air limbah rumah makan salah satu Kota Pontianak yang diambil berasal dari komposit semua hasil limbah cuci piring dan bahan makanan pada pagi hari hingga siang hari . Hewan uji yang digunakan adalah ikan mas (Cyprinus carpio Linn.) yang diambil dari tambak ikan Dinas 
Perikanan Provinsi Kalimantan Barat sebanyak 300 ekor berumur 1-1,5 bulan dengan panjang tubuh $6-7 \mathrm{~cm}$.

\section{PROSEDUR PENELITIAN}

- Aklimasi Hewan Uji dan Pengambilan Sampel Limbah Rumah makan

Penelitian ini merupakan penelitian dalam skala laboratorium dimana sampel limbah cair yang diambil berasal dari komposit semua hasil limbah cuci piring pada pagi hari hingga siang hari sebelum dibuang ke badan perairan. Sampel limbah cair disimpan terlebih dahulu di dalam jerigen agar tidak mengalami kontak dengan udara. Parameter fisika dan kimia yang menjadi data pendukung penelitian antara lain adalah BOD, pH, minyak lemak, TSS dan suhu. Air limbah rumah makan diuji di Laboratorium PT.SUCOFINDO, kemudian dibandingkan dengan baku mutu KEP/MENLH/ No. 5 Tahun 2014 .

Hewan uji ikan mas diaklimasi dulu untuk memberikan waktu hewan uji beradaptasi dengan lingkungan barunya. Air di dalam akuarium tersebut dikondisikan agar mempunyai temperatur antara $25-30^{\circ} \mathrm{C}$. Penggantian air di dalam media aklimasi dilakukan apabila air tersebut sudah terlalu keruh dan aklimasi dilakukan selama 7 hari. Dalam rentang waktu 7 hari biota air uji ikan mas akan diberi makan pelet ikan setiap hari sekali serta diberi aerasi yang cukup untuk mempertahankan kadar oksigen terlarut.

- Uji Pendahuluan

Uji pendahuluan dilakukan untuk menentukan batas kisaran kritis (critical range test) yang menjadi dasar dari penentuan konsentrasi yang digunakan dalam uji lanjutan atau uji toksisitas yang sesungguhnya, yaitu konsentrasi yang dapat menyebabkan kematian terbesar mendekati 50\% dan kematian terkecil mendekati 50\% . Percobaan dilakukan dengan 5 variasi pengenceran limbah rumah makan dan satu sebagai kontrol. Percobaan ini dilakukan dengan dua kali pengulangan atau duplo. US.EPA (2002) merekomendasikan konsentrasi limbahnya antara lain 10; 20; 30; 40; $50 \%$.

- Uji Lanjut

Uji lanjut dilakukan terhadap limbah rumah makan Kota Pontianak dengan variasi konsentrasi yang berada pada rentang dimana nilai $\mathrm{LC}_{50}$ uji pendahuluan berada didalamnya. Uji lanjut dilakukan dengan waktu pengamatan 24 jam dan setiap 6 jam diamati. Uji lanjut dilakukan dengan tahapan sebagai berikut:

a. Konsentrasi limbah rumah makan didapat dari uji pendahuluan yaitu $0,4 \% ; 0,5 \%$; $0,6 \% ; 0,7 \%$ dan $0,8 \%$. Konsentrasi setiap perlakuan dibuat dengan rumus pengenceran.

$$
\mathrm{V} 1 . \mathrm{M} 1=\mathrm{V} 2 . \mathrm{M} 2
$$

Konsentrasi limbah 0,4\% $=0,08 \mathrm{~L}$ air limbah $+19,92 \mathrm{~L}$ air galon

b. Ikan mas (Cyprinus carpio Linn) sebanyak 10 ekor tiap ulangan ditempatkan di dalam wadah yang berisi $10 \mathrm{~L}$ campuran air galon dan air limbah .

c. Parameter yang diamati adalah jumlah ikan yang mengalami kematian dalam jangka waktu 24 jam. Hasil uji dapat diterima apabila 90\% hewan uji pada kontrol di akhir pengamatan masih hidup. Apabila yang bertahan hidup lebih kecil dari $90 \%$ maka uji harus diulang. 


\section{ANALISA DATA}

Parameter fisika dan kimia yang menjadi data pendukung penelitian antara lain adalah BOD, pH, minyak lemak, TSS, dan suhu. Air limbah rumah makan diuji terlebih dahulu di Laboratorium PT.SUCOFINDO untuk mencari nilai parameter pendukung di atas dan dibandingkan dengan baku mutu KEP/MENLH/ No. 5 Tahun 2014. Metode yang digunakan untuk mengestimasi nilai $\mathrm{LC}_{50}$ dalam penelitian ini adalah metode Probit dengan ketentuan uji hayati dari APHA (1995) mengambil uji statik test dan dalam jangka waktu 24 jam atau 1 hari selama pemberian limbah.

Variasi konsentrasi dibuat dengan total pencampuran kedua air tersebut $20 \mathrm{~L}$. Pertama dibuat campuran larutan $10 \%$ (2 L limbah dengan $18 \mathrm{~L}$ air galon) dan seterusnya seperti itu kepada ikan mas selama 24 jam atau 1 hari. Setelah mendapatkan jumlah ikan yang mati dihitung $\%$ mortalitasnya dengan rumus mortalitas $=$ [(jumlah yang mati/jumlah total ikan) x 100\%], dilanjutkan dengan pengisian data di worksheet MINITAB untuk mendapatkan hasil $\mathrm{LC}_{50}$.

\section{HASIL DAN PEMBAHASAN}

A. Karakteristik Limbah Salah Satu Rumah Makan di Kota Pontianak

Air limbah yang dihasilkan salah satu rumah makan di kota Pontianak dalam satu hari berjumlah lebih dari $60 \mathrm{~L}$. Air limbah tersebut berasal dari komposit semua hasil limbah cuci piring dan bahan makanan pada pagi hari hingga siang hari sebelum dibuang ke badan perairan. Hasil pengujian yang dilakukan terhadap kualitas baku mutu air limbah tersebut mengacu kepada KEP/MENLH/ No. 5 Tahun 2014. Data kualitas air limbah rumah makan kondisi baru diambil dapat dilihat pada Tabel 1:

Tabel 1. Perbandingan Hasil Analisis Limbah Cair Rumah Makan dengan Baku Mutu

\begin{tabular}{|c|c|c|c|c|}
\hline No & Parameter & Satuan & Baku Mutu & Kadar (mg/l) \\
\hline 1 & BOD & $\mathrm{mg} / \mathrm{l}$ & 100 & 692,48 \\
2 & TSS & $\mathrm{mg} / \mathrm{l}$ & 100 & 1700 \\
3 & Minyak Lemak & $\mathrm{mg} / \mathrm{l}$ & 10 & 46 \\
4 & $\mathrm{pH}$ & - & $6-9$ & 6,59 \\
5 & Suhu & ${ }^{\circ} \mathrm{C}$ & 30 & 25,8 \\
\hline
\end{tabular}

Berdasarkan data dari Tabel 1 dapat dilihat bahwa nilai BOD, TSS dan minyak lemak melewati baku mutu yang ditetapkan oleh KEP/MENLH/ No.5 Tahun 2014. Nilai yang didapat berbeda dengan nilai karakteristik limbah cair rumah makan Raje Laot di Kota Pontianak pada penelitian Wiwien (2014) dimana nilai masing-masing parameter yang didapat untuk BOD, pH, TSS dan Minyak Lemak sebesar 118,64 mg/l; 5,31; 312 $\mathrm{mg} / \mathrm{l}$ dan $315 \mathrm{mg} / \mathrm{l}$. Terdapat perbedaan yang cukup besar pada nilai BOD dan TSS dimana penelitian ini memiliki nilai yang lebih besar. Perbedaan tersebut dapat terjadi dikarenakan pada saat pengambilan limbah, limbah yang ditampung Wiwien (2014) dibiarkan selama beberapa jam dalam kondisi terbuka (aerob), sehingga menyebabkan nilai BOD yang terkandung terdegradasi oleh oksigen $\left(\mathrm{O}_{2}\right)$. Waktu untuk penampungan limbah juga mempengaruhi nilai minyak lemak dimana minyak lemak penelitian ini memiliki nilai yang lebih kecil dibanding penelitian Wiwien (2014). Semakin lama menampung limbah maka minyak lemak yang terkandung akan membentuk lapisan pada permukaan air, hal ini disebabkan massa jenis minyak lebih kecil dibandingkan air. 
Tingginya nilai minyak lemak juga dapat dikaitkan dengan jumlah pelanggan yang datang, semakin banyak pelanggan yang datang maka semakin banyak cucian piring dan penggorengan makanan yang dilakukan, dikarenakan rumah makan Raje Laot termasuk salah satu rumah makan besar di Kota Pontianak.

Nilai BOD menunjukkan jumlah oksigen terlarut yang dibutuhkan oleh mikroorganisme untuk memecahkan atau mengoksidasi bahan-bahan organik menjadi karbondioksida $\left(\mathrm{CO}_{2}\right)$ dan air $\left(\mathrm{H}_{2} \mathrm{O}\right)$ (Jenie \& Rahayu, 1993). Semakin tinggi nilai BOD yang terkandung di dalam limbah tersebut maka semakin rendah kandungan DO yang ada. (Effendi, 2003). TSS merupakan salah satu faktor penting terjadinya kekeruhan di badan air dikarenakan adanya kandungan zat tersuspensi. Dengan tidak adanya pengolahan limbah (IPAL) pada rumah makan, maka akan berbahaya jika limbah langsung dibuang ke badan air, salah satu contohnya kandungan minyak lemak. Berat jenis minyak lebih kecil dari air sehingga minyak akan membentuk lapisan tipis di permukaan air dan menutup permukaan yang mengakibatkan terbatasnya oksigen masuk ke dalam air. Pada sebagian lain minyak ini membentuk lumpur dan mengendap sehingga sulit diuraikan (Ginting, 2007).

\section{B. UJI TOKSISITAS AKUT}

- Uji Pendahuluan

Uji pendahuluan bertujuan untuk mengetahui kematian yang terjadi dengan menggunakan rekomendasi variasi konsentrasi dari US.EPA, (2002). Jumlah kematian ikan mas (Cyprinus carpio L.) pada uji pendahuluan I selama 24 jam dengan jumlah 10 ekor ikan dapat dilihat pada Gambar 1:

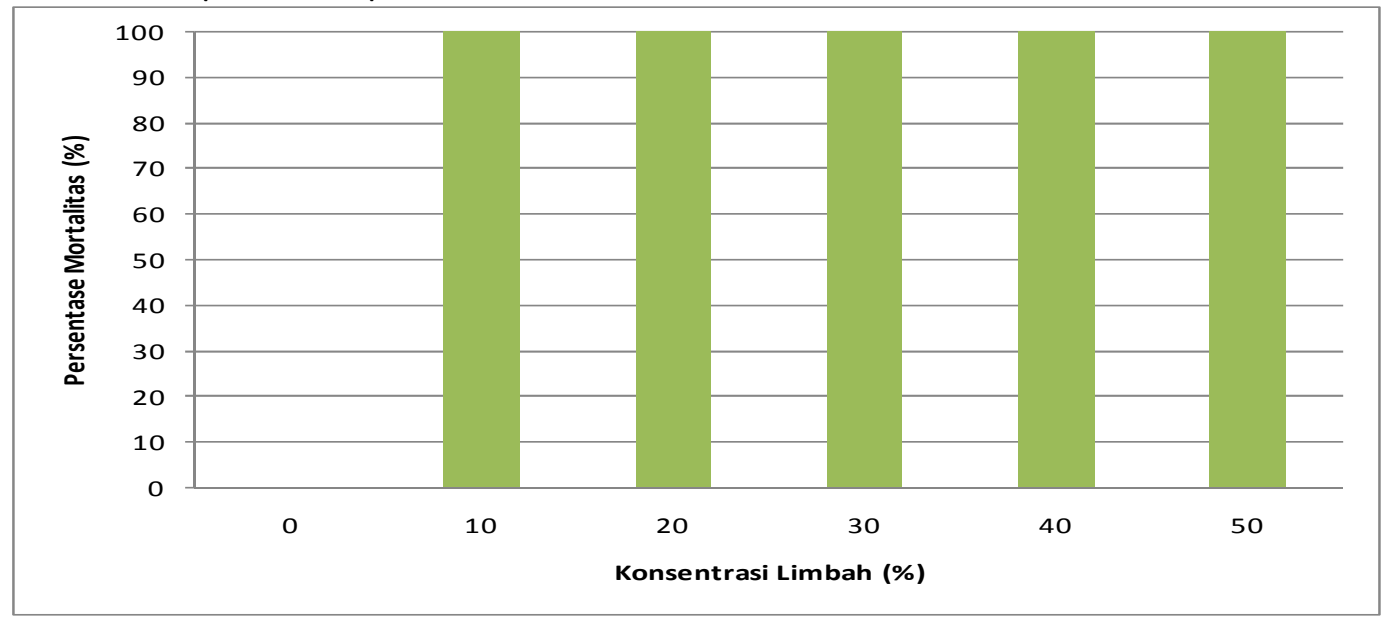

Gambar 1. Grafik Presentase Kematian Ikan pada Uji Pendahuluan I

Persentase mortalitas ikan pada uji pendahuluan I memperlihatkan kematian $100 \%$ di setiap variasi konsentrasi, maka nilai konsentrasi pada uji pendahuluan I tidak dapat digunakan untuk menentukan batas kisaran kritis kematian, konsentrasi uji pendahuluan ke Il yang dipakai diturunkan menjadi konsentrasi yang lebih kecil daripada konsentrasi terkecil uji pendahuluan I (10\%).

Variasi konsentrasi uji pendahuluan II mengacu pada penelitian Husni dan Esmiralda (2010) dan dibuat 5 konsentrasi baru yaitu 0,5\%; 1\%; 1,5\%; 2\%; 2,5\%. Uji pendahuluan II menggunakan 10 ekor ikan, hasil yang diperoleh dapat dilihat pada Gambar 2 : 


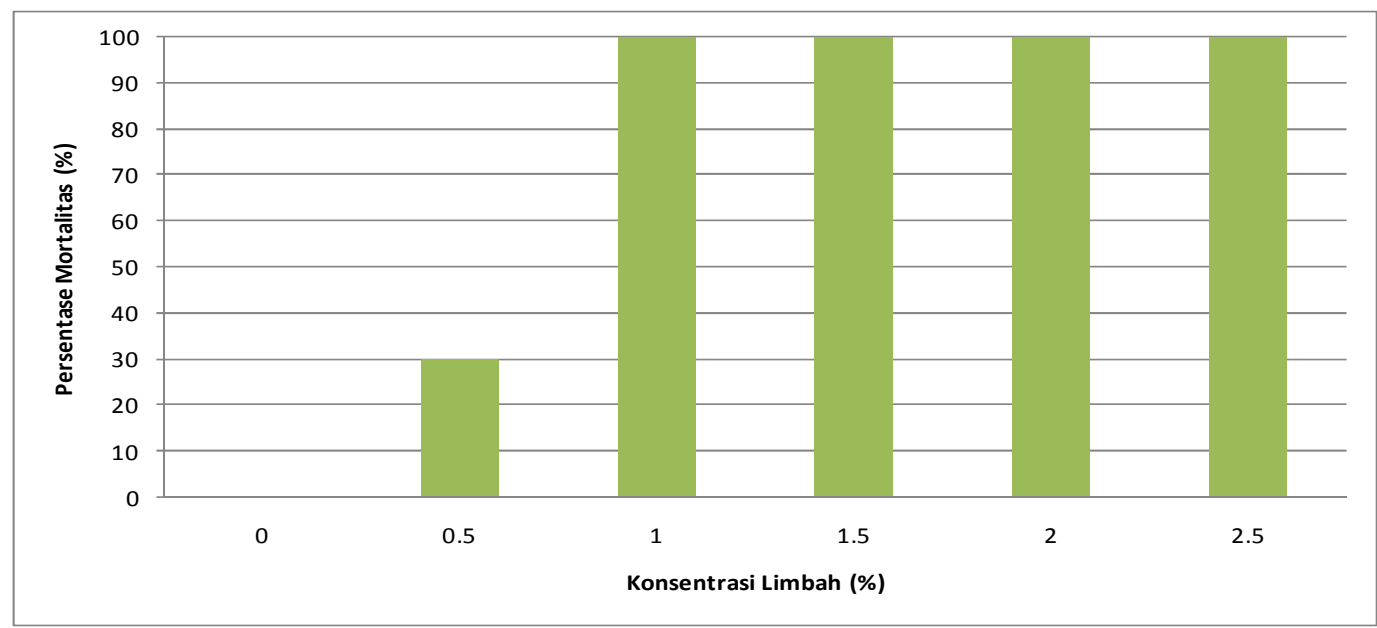

Gambar 2. Grafik Persentase Kematian Ikan pada Uji Pendahuluan II

Berdasarkan hasil uji pendahuluan II diperoleh kematian 100\% pada tiap konsentrasi limbah kecuali pada konsentrasi $0 \%$ (kontrol) yang tidak mengalami kematian dan $0,5 \%$ yang mengalami kematian sebanyak 3 ekor dengan persentase mortalitas sebesar 30\%. Berdasarkan hasil mortalitas uji Pendahuluan II dapat dikatakan bahwa kisaran konsentrasi terendah yang tidak mengalami kematian $100 \%$ adalah 0,5\% dan kisaran tertinggi yang mengalami kematian $100 \%$ adalah $1 \%$. Perlunya dilakukan uji lanjut dengan variasi konsentrasi terbaru yaitu $0,4 \% ; 0,5 \% ; 0,6 \% ; 0,7 \%$; dan $0,8 \%$. Seperti yang terjadi pada uji pendahuluan I, hewan uji pada kontrol tidak mengalami kematian sehingga kematian yang terjadi pada variasi konsentrasi lain bukan disebabkan faktor eksternal seperti jenis wadah yang digunakan, tidak diberikannya makan kepada hewan percobaan dan supply oksigen oleh aerator yang tidak diberikan selama pengujian berlangsung.

- Uji Lanjut

Penelitian pada uji lanjut sama seperti uji pendahuluan I dan II yang menggunakan 10 ekor ikan dan duplo. Setelah mendapatkan range terendah dan tertinggi untuk variasi konsentrasi limbah yang diberikan pada ikan mas selama 24 jam, maka jumlah kematian ikan mas (Cyprinus carpio L.) yang diperoleh dari uji lanjut dapat dilihat pada Gambar 3 :

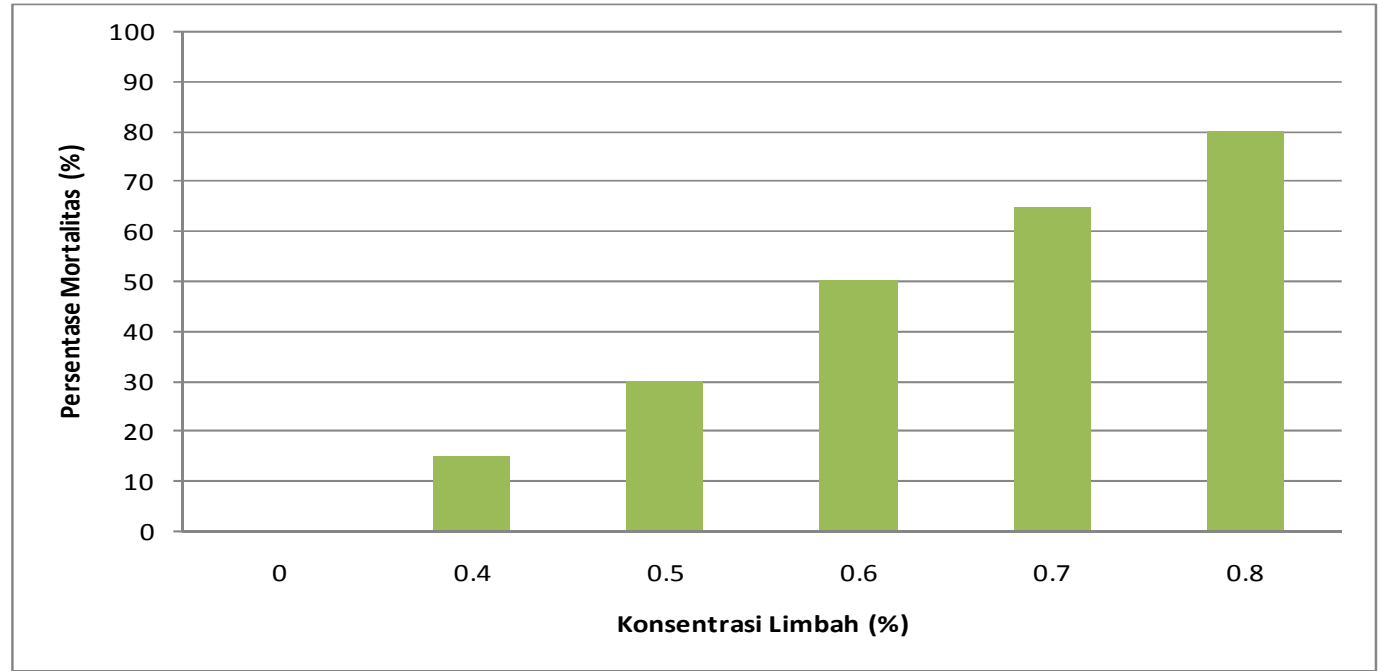

Gambar 3. Grafik Persentase Mortalitas Ikan pada Uji Lanjut 
Pada Gambar 3 ditunjukkan bahwa pemaparan air limbah rumah makan terhadap ikan uji dengan konsentrasi $0,4 \% ; 0,5 \% ; 0,6 \% ; 0,7 \%$ dan $0,8 \%$ didapatkan persentase mortalitas ikan rata-rata untuk setiap konsentrasi yaitu 15\%; 30\%; 50\%; 65\% dan 80\%. Pemaparan ikan uji dengan air limbah rumah makan hanya dilakukan dalam durasi 24 jam, namun telah mematikan ikan uji sebanyak $50 \%$ atau lebih pada konsentrasi $0,6 \%$ ke atas. Berdasarkan hasil ini didapatkan bahwa limbah cair rumah makan merupakan zat toksikan yang mempunyai efek akut terhadap suatu biota yang hidup di perairan. Suatu zat toksikan dapat dikatakan toksisitas akut terhadap organisme apabila zat tersebut mampu mematikan dalam jangka waktu tidak lebih dari 14 hari (Mangkoedihardjo, 1999).

Pada penelitian yang dilakukan Halang (2004) menggunakan limbah deterjen sebagai toksikan dan diperlakukan terhadap ikan mas dengan variasi konsentrasi $0 \mathrm{mg} / \mathrm{l}$, $10 \mathrm{mg} / \mathrm{l}, 20 \mathrm{mg} / \mathrm{l}, 30 \mathrm{mg} / \mathrm{l}, 40 \mathrm{mg} / \mathrm{l}$ dan $50 \mathrm{mg} / \mathrm{l}$, didapatkan $\mathrm{LC}_{50}$ selama 96 jam terjadi pada konsentrasi $40 \mathrm{mg} / \mathrm{l}$ ke atas, sedangkan konsentrasi yang lebih rendah diperkirakan mati dalam 14 hari dan zat toksikan ini mempunyai efek akut.

Hewan uji kontrol untuk Uji Pendahuluan dan Uji Lanjut tidak mengalami kematian sehingga kematian yang terjadi pada variasi konsentrasi lain bukan disebabkan faktor eksternal seperti jenis wadah yang digunakan, tidak diberikannya makan kepada hewan percobaan dan supply oksigen oleh aerator yang tidak diberikan selama pengujian berlangsung.

Racun yang masuk ke badan air dapat langsung menyebabkan kematian pada organisme yang terdapat di daerah tersebut. Tetapi pada konsentrasi yang lebih rendah dapat menyebabkan terganggunya fungsi organisme tersebut. Akibat yang disebabkan oleh racun yang tidak menyebabkan kematian secara langsung disebut efek sub lethal (Mason, 1980). Seperti pada konsentrasi 0,4\% dan 0,5\% pada saat terpapar limbah pertama kali ikan masih berenang dengan aktif seperti hewan uji kontrol. Pada pengamatan 12 jam setelah pemberian limbah ikan masih aktif berenang dan naik ke permukaan untuk mengambil $\mathrm{O}_{2}$, namun setelah 18 jam ikan cenderung di dasar dan ada yang mulai mengalami kejang-kejang dan berujung pada kematian.

Dapat ditarik kesimpulan bahwa semakin tinggi konsentrasi limbah maka semakin banyak kematian ikan mas sedangkan semakin rendah konsentrasi limbah maka semakin sedikit jumlah ikan mas yang mati. Hal ini serupa dengan penelitian yang dilakukan Karnilawati (2007), bahwa semakin tinggi konsentrasi limbah cair maka mortalitas ikan mas semakin meningkat. Apabila pada perairan terkontaminasi dengan limbah organik yang memiliki kadar cukup tinggi maka kadar oksigen terlarut dalam perairan tersebut mengalami pengurangan dengan cepat (Effendi, 2003).

\section{NILAI LC 50 RATA-RATA}

Hasil dari kedua uji dasar yang dilakukan secara duplo terhadap jenis sampel limbah cair salah satu rumah makan di Kota Pontianak, diperoleh dua variasi nilai $\mathrm{LC}_{50}$. Dapat dilihat Gambar 4 dibawah ini nilai $\mathrm{LC}_{50}$ rata-rata dari kedua percobaan ikan pada sampel limbah cair rumah makan salah satu Kota Pontianak: 


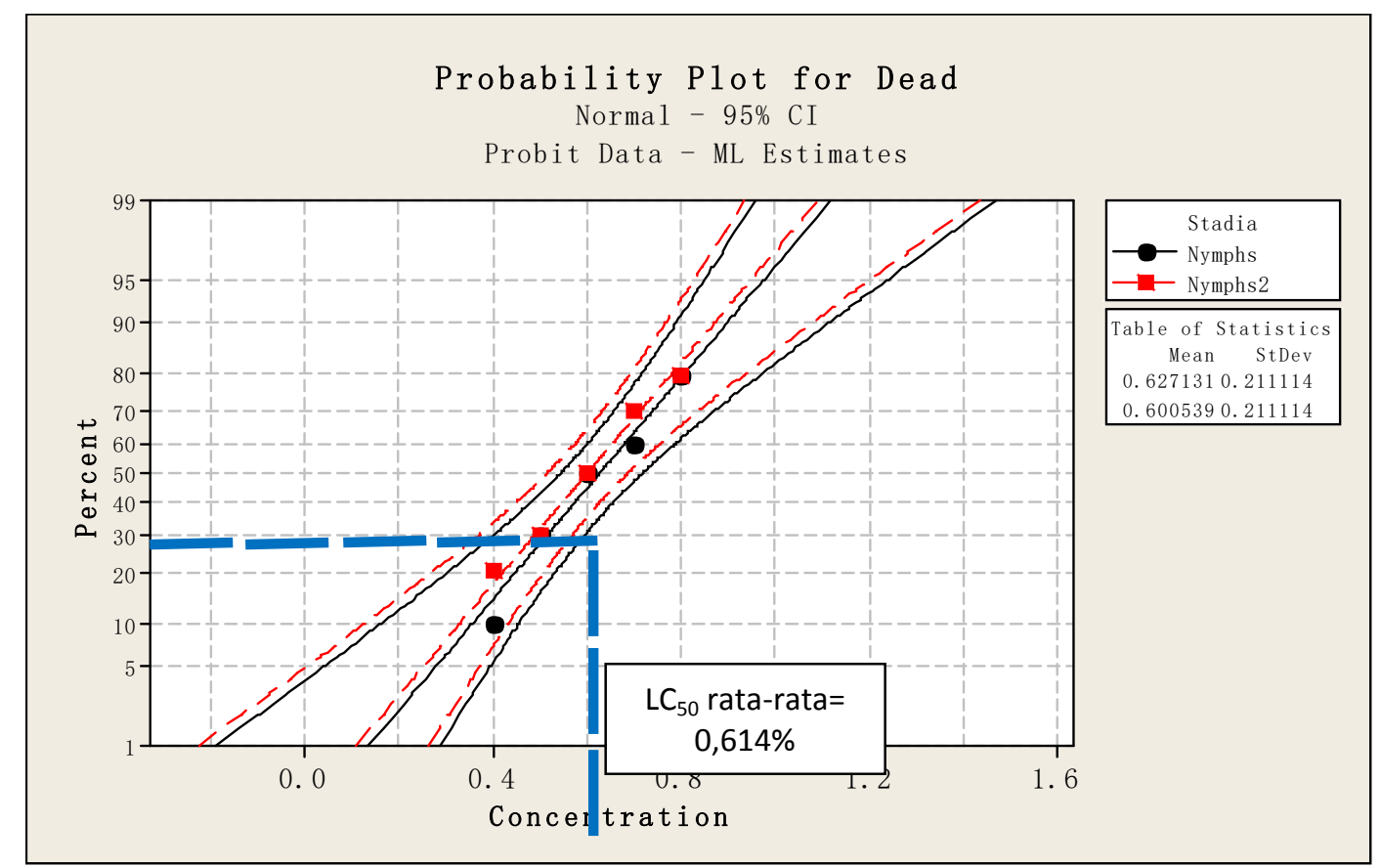

Gambar 4. Nilai Rata-rata $\mathrm{LC}_{50}$ dari Dua Percobaan Ikan mas (Cyprinus carpio L.)

Dapat dilihat dari gambar 4 diatas garis putus-putus berwarna biru menunjukkan titik potong dengan garis linear kematian rata-rata merupakan nilai $\mathrm{LC}_{50}$ yaitu $0,614 \%$. Perbedaan nilai $\mathrm{LC}_{50}$ antara 2 ulangan percobaan tersebut dipengaruhi oleh perbedaan kemampuan daya tahan tubuh masing-masing ikan mas sehingga menghasilkan angka yang berbeda pada jumlah kematian.

\section{ANALISIS HUBUNGAN KARAKTERISTIK LIMBAH CAIR RUMAH MAKAN TERHADAP KEMATIAN IKAN}

Karakteristik limbah cair rumah makan yang diuji pada laboratorium adalah BOD, TSS, Minyak Lemak, pH dan suhu. Penelitian ini membahas tentang analisis hubungan karakteristik limbah cair rumah makan yaitu BOD, TSS, dan minyak Lemak terhadap kematian ikan. Karakteristik limbah tersebut merupakan karakteristik utama yang memiliki hubungan terhadap jumlah kematian hewan uji.

- Hubungan BOD Limbah Cair Rumah Makan Terhadap Kematian Ikan mas

Kematian ikan yang terjadi pada penelitian ini disebabkan beberapa faktor salah satunya berkaitan dengan nilai BOD yang tinggi, nilai BOD yang didapat pada penelitian ini sebesar $692,48 \mathrm{mg} / \mathrm{l}$. Semakin tinggi nilai BOD akan menyebabkan turunnya nilai oksigen terlarut (DO) (Effendi, 2003).

- Hubungan TSS Limbah Cair Rumah Makan Terhadap Kematian Ikan mas

Zat Padat Tersuspensi (TSS) dibagi menjadi zat padat terapung yang bersifat organis dan zat padat terendap yang bersifat organis dan inorganis. Padatan tersuspensi akan mengurangi penetrasi sinar matahari ke dalam air sehingga akan mempengaruhi regenerasi oksigen serta fotosintesis (Fardiaz, 1992). Nilai TSS yang didapat pada penelitian ini sebesar $1700 \mathrm{mg} / \mathrm{l}$ dan melewati nilai baku mutu. TSS dalam jumlah yang berlebih dapat menyebabkan penyumbatan filamen insang ikan atau selaput pernapasan lainnya, sehingga asupan oksigen oleh ikan menjadi berkurang karena terlapisi oleh padatan (Effendi, 2003). 
Tingkat kekeruhan akan mempengaruhi kelarutan oksigen dalam air. Semakin keruh air yang digunakan, ikan semakin sulit bernapas karena kekurangan oksigen. Selain itu, insang akan tertutup oleh partikel-partikel lumpur, batas pandang ikan berkurang, dan nafsu makan berkurang (Pribadi, 2002).

- Hubungan Minyak Lemak Limbah Cair Rumah Makan terhadap Kematian Ikan mas Nilai minyak lemak yang didapat pada penelitian ini sebesar $46 \mathrm{mg} / \mathrm{l}$ dan melewati nilai baku mutu. Minyak adalah zat yang tidak dapat larut dalam air melainkan akan mengapung di atas permukaan air, yang berarti bahwa bahan buangan mengandung minyak lemak akan menutupi permukaan air dan mengganggu kehidupan organisme di bawahnya. Minyak lemak juga membentuk lapisan pada permukaan insang dan selaput pernafasan lainnya, sehingga menghalangi difusi oksigen ke dalam sel tubuh ikan.

E. Rekomendasi Bagi Pemerintah

Dari hasil penelitian yang dilakukan didapatkan nilai BOD yang terkandung di dalam limbah tersebut sebesar 692,48 mg/l, nilai TSS sebesar $1700 \mathrm{mg} / \mathrm{l}$ dan minyak lemak $46 \mathrm{mg} / \mathrm{l}$. Nilai tersebut melewati baku mutu yang ditetapkan oleh KEP/MENLH/ No.5 Tahun.

Peraturan tentang pengolahan limbah cair Rumah Makan sebelum dibuang ke badan air tercantum di dalam PERDA Walikota Pontianak No.03 Tahun 2004 pasal 9 ayat 3 yang berbunyi " Bahwa setiap rumah makan yang ada di Kota Pontianak diwajibkan untuk mengolah limbah cairnya sebelum dibuang ke lingkungan“. Pengolahan limbah cair dapat dilakukan dengan bangunan Instalasi Pengolahan Air Limbah (IPAL).

\section{KESIMPULAN}

Berdasarkan hasil dan pembahasan yang didapatkan, penelitian mengenai uji toksisitas akut $\left(\mathrm{LC}_{50}\right)$ limbah cair salah satu rumah makan di Kota Pontianak terhadap ikan mas (Cyprinus carpio L.), dapat diambil beberapa kesimpulan sebagai berikut :

1. Hasil uji laboratorium yang dilakukan terhadap limbah cair salah satu rumah makan di Kota Pontianak didapatkan Nilai BOD yang terkandung di dalam limbah tersebut sebesar 692,48 mg/l, nilai TSS sebesar 1700 mg/l, Minyak lemak 46 mg/l, suhu sebesar 25,8 oC dan $\mathrm{pH} 7,03$.

2. Nilai konsentrasi $\mathrm{LC}_{50}$ rata-rata limbah rumah makan terhadap ikan mas (Cyprinus carpio L.) yang didapatkan dari metode probit sebesar $0,614 \%$.

3. Rekomendasi untuk pemerintah perlu dilakukan pengecekan terhadap setiap rumah makan yang ada di Kota Pontianak untuk mengetahui apakah rumah makan tersebut sudah memiliki IPAL (Instalasi Pengolahan Air Limbah) sebelum membuang limbahnya ke badan perairan seperti yang tercantum didalam PERDA Pontianak No.03 Tahun 2004.

\section{UCAPAN TERIMA KASIH}

Terima kasih saya ucapkan sebesar-besarnya kepada Allah SWT karena dengan rahmatnya penelitian ini bisa selesai dengan tepat waktu. Terimakasih juga kepada orang tua, abang, adik, pacar serta teman-teman yang selalu membantu dan mendukung saya dalam perkuliahan sampai di akhir semester ini.

Terima kasih saya ucapkan untuk dosen-dosen pembimbing dan penguji saya beserta staff-staff prodi teknik lingkungan yang memberikan saya kesempatan untuk belajar. 


\section{DAFTAR PUSTAKA}

Alaerts, G dan Santika, SS. 1987. Metoda Penelitian Air. Usaha Nasional, Surabaya.

APHA. 1995. Standard Method for The Examination of Water and Waste water. American Public Health Association,American Water Works Association and Water Polution Control Federation 19th edition. Washington D.C.

Effendi, H. 2003. Telaah Kualitas Air bagi Pengelolaan Sumber Daya dan Lingkungan Perairan. Cetakan Kelima. Yogjakarta : Kanisius.

Fardiaz, S., 1992. Mikrobiologi Pangan I. Gramedia Pustaka Utama, Jakarta.

Ginting, P. 2007. Sistem Pengelolaan Lingkungan Dan Limbah Industri. Cetakan pertama. Bandung: Yrama Widya. Hal 37-200.

Halang, B. 2004. Toksisitas Air Limbah Deterjen Terhadap Ikan Mas (Cyprinus carprio L). Bioscientine. 1 (1) : $39-49$.

Husni, H dan Esmiralda. 2011. Uji Toksisitas Akut Limbah Cair Industri Tahu Terhadap Ikan Mas ( Cyprinus carpio Linn ). Universitas Andalas. Padang

Husni. H. 2012. Uji Toksisitas Akut Limbah Cair Industri Tahu Terhadap Ikan Mas (Cyprinus carpio Linn). Universitas Andalas. Padang. Skripsi. Tidak dipublikasikan.

Jenie. B.S.L. \& W.P. Rahayu, 1993, Penanganan Limbah Industri Pangan, Penebit, Kanisius, Yogyakarta.

Karnilawati. 2007. Pengaruh pemberian limbah lateks terhadap kelangsungan hidup ikan mas (Cyprinus carpio). Skripsi. Program Studi Budidaya Perairan Fakultas Pertanian. Universitas Sriwijaya. Indralaya. (Tidak dipublikasikan).

Mangkoedihardjo. 1999. Ekotoksikologi Keteknikan. Jurusan Teknik Lingkungan. ITS. Surabaya

Mardianto, W. 2014. Pengolahan Limbah Cair Rumah Makan Menggunakan Sistem Kombinasi ABR dan Wetland dengan Sistem Kontinyu. Program Studi Teknik Lingkungan. Universitas Tanjungpura. Pontianak.

Mason, C.F. 1980. Biological of Fresh Water Pollution. London. New York.

Pribadi, T.S., Muharnanto, Endah. J., Listyarini.T dan Herlina. R., 2002. Pembesaran Ikan Mas di Kolam Air Deras. Agromedia Putaka, Jakarta.

Rossiana, Nia. 2006. Uji Toksisitas Limbah Cair Tahu Sumedang terhadap Reproduksi Daphnia carinata KING. Jurnal Biologi. Jurusan Biologi Fakultas Matematika dan Ilmu Pengetahuan Alam Universitas Padjajaran: Bandung

Sudarmadi, Sigit. 1993. Toksikologi Limbah Pabrik Kulit terhadap Cyprinus Carpio L dan Kerusakan Insang. Jurnal Lingkungan dan Pembangunan 13;4: Jakarta. 